\title{
Ammi visnaga (L.) Lam. (Apiaceae), a new taxon in Croatian flora
}

\author{
MirKo RuŠČIĆ ${ }^{1}$, TONI NiKOLIĆ2* \\ ${ }^{1}$ University of Split, Faculty of Science, Department of Biology, Teslina 12, \\ HR-21000 Split, Croatia \\ ${ }^{2}$ University of Zagreb, Faculty of Science, Department of Botany and Botanical \\ Garden, Marulićev trg 9a, HR-10000 Zagreb, Croatia
}

\begin{abstract}
During floristic research into the island of Brač (Dalmatia, Croatia) in 2010, Ammi visnaga (L.) Lam. (Apiaceae), a new neophyte for Croatia was found in several localities and natural habitats. At the altitude of 380-460 m above sea level, mostly in habitats disturbed by humans, the located populations were composed of numerous and vital specimens in blooms and with fruits. The gradual and successful integration of this species into the natural vegetation was noticed, particularly in grasslands of the association Brachypodio retuso-Trifolietum stellati Horvatić 1958 and macchia of the association Fraxino orno-Quercetum ilicis Horvatić (1956) 1958.
\end{abstract}

Key words: Ammi visnaga, flora, neophyte, island Brač, Croatia

\section{Introduction}

The genus Ammi L. (Apiaceae) contains about 25 species. This taxon of European origin is distributed mostly in the Mediterranean region, North Africa, and in south-west Asia (Tutin 1968). Because of their particular and useful chemical compounds (in the first place 4, 9-Dimethoxy-7-methylfuro [3, 2-g] chromen-5-one or khellin, but also other compounds) plants of the genus Ammi have a long tradition of usage in ethno-medicine (Batanouny et al. 1999: 207, Chevallier 2001). Several Ammi species are cultivated in the area of natural distribution, but some taxa are introduced into the culture in other continents as well (i.e. North America), where naturalization occasionally occurs.

In Europe several taxa are indigenous: Ammi crinitum Guss., A. huntii H. C. Watson (endemic for the Azores, incl. A. seubertianum (H. C. Watson) Trelease), A. majus L. (incl. A. topalii Beauverd), A. trifoliatum (H. C. Watson) Trelease (endemic for the Azores), and A. visnaga (L.) Lam. (Tutin 1968, Pignatti 1982, Bueno et al. 2006).

* Corresponding author, e-mail: toni@botanic.hr

Copyright ${ }^{\circledR} 2011$ by Acta Botanica Croatica, the Faculty of Science, University of Zagreb. All rights reserved. 
In the flora of Croatia the genus was previously represented with one species - Ammi majus L. (NiKOLIĆ 2011).

\section{Material and methods}

Floristic investigations of the island of Brač were performed during 2006-2010. (RUŠČIĆ 2010). Specimens of the genus Ammi L. were collected, but these plants did not match the description of the already known Ammi majus (DomAC 1994). Additional determinations were performed using Tutin (1968) and PignatTi (1982).

All localities where plants were noticed were geo-coded by using a GPS device with an accuracy that alternated horizontally on the field between \pm 5 up to $\pm 50 \mathrm{~m}$. The basic geo-reference propositions (ellipsoid, projection, date, zone) are in accordance with NIKOLIĆ (2006). The MTB 64 mapping square identification mark was added to all findings (NIKOLIĆ et al. 1998). A herbarium specimen (voucher) is placed in Herbarium Croaticum (ZA, specimen id. 27668). The data were recorded in the Flora Croatica database (NIKOLIĆ 2011).

\section{Results and discussion}

Of the five European taxa of the genus Ammi (Tutin 1968: 353), in the Croatian flora only A. majus was known (NIKolić 2011). During floristic investigation of the island of Brač (central Dalmatia) a new taxon for Croatian flora, Ammi visnaga (L.) Lam. (Flore Françoise 3: 462, 1778) (= Daucus visnaga L., Species Plantarum 1: 242, 1753) was established (Fig. 1).

The key for distinction of the two Ammi species in Croatian flora is as follow:

1. Rays patent or erecto-patent in flower; in fruit become erect, thickened and indurate; basal leaves with linear leaflets $(0.3-0.5 \times 3-6 \mathrm{~mm})$, leaflets margin entire

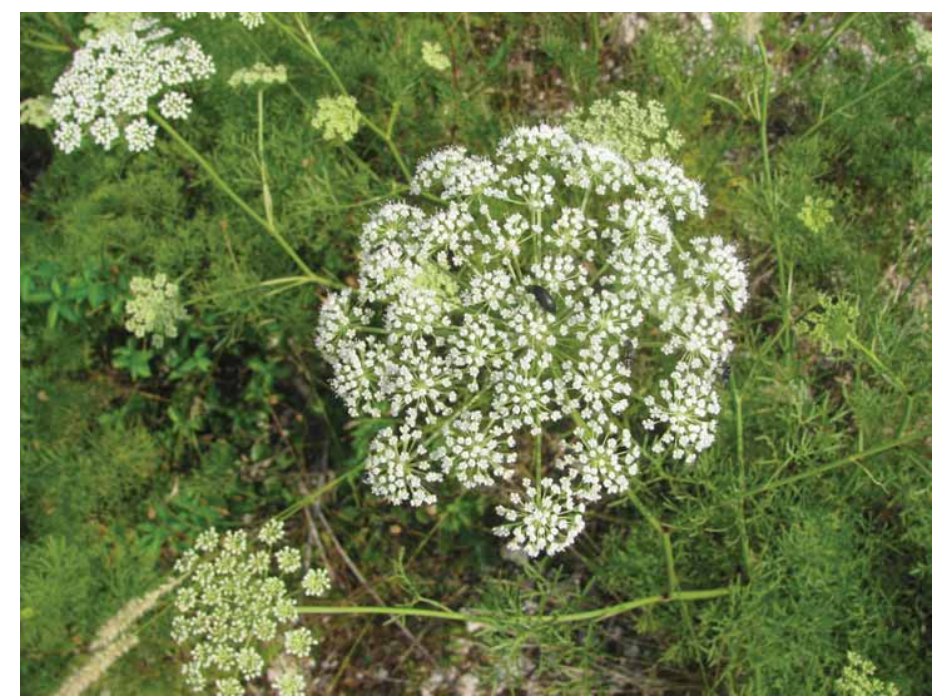

Fig. 1. Ammi visnaga (L.) Lam. (Apiaceae) from Brač (Dalmatia, Croatia) (photo M. Ruščić). 


\section{Ammi visnaga}

2. Rays patent and slender in flower and fruit; basal leaves with lanceolate leaflets (1-3 x 3-6 mm), leaflets margin dentate

\section{Ammi majus}

Ammi visnaga is a robust annual or biennial plant, with height up to $100 \mathrm{~cm}$. The root is fattened and looks like the root of the carrot. Lower leaves are pinnate, others 2- to 3-pinnate, all with narrowly linear or filiforme lobes. Rays are numerous (30-50, up to 150), slender and patent or erecto-patent in the flower. In the fruit, rays become erect, thickened and indurate. Bracts are 1- to 2-pinnatisect, equalling or exceeding the rays. Bracteoles are subulate. Flowers are pentamerous, tetracyclic, with radial symmetry, with five stamens and inferior ovary composed from two united carpels. Petal colour is amber. Plants usually flower from May to September, and on the island of Brač up to October. Fruit is dry, 2-2.5 mm long, with two mericarpes, characteristic of the family (TuTin 1968, PignATTI 1982).

In comparison, Ammi majus have patent rays and are slender in flower and fruit. There are fewer rays (15-30, up to 60). Basal leaves are compounded of lanceolate leaflets (1-3 x 3-6 mm), the leaflet margin being dentate. Petal colour is white-amber. The fruits are smaller (1.5-2 mm).

The Ammi visnaga were recorded in three localities in the central part of Brač, along the road that connects the villages Pražnica and Gornji Humac (Tab. 1, Fig. 2). All localities are placed inside the mapping square MTB 2666.33.
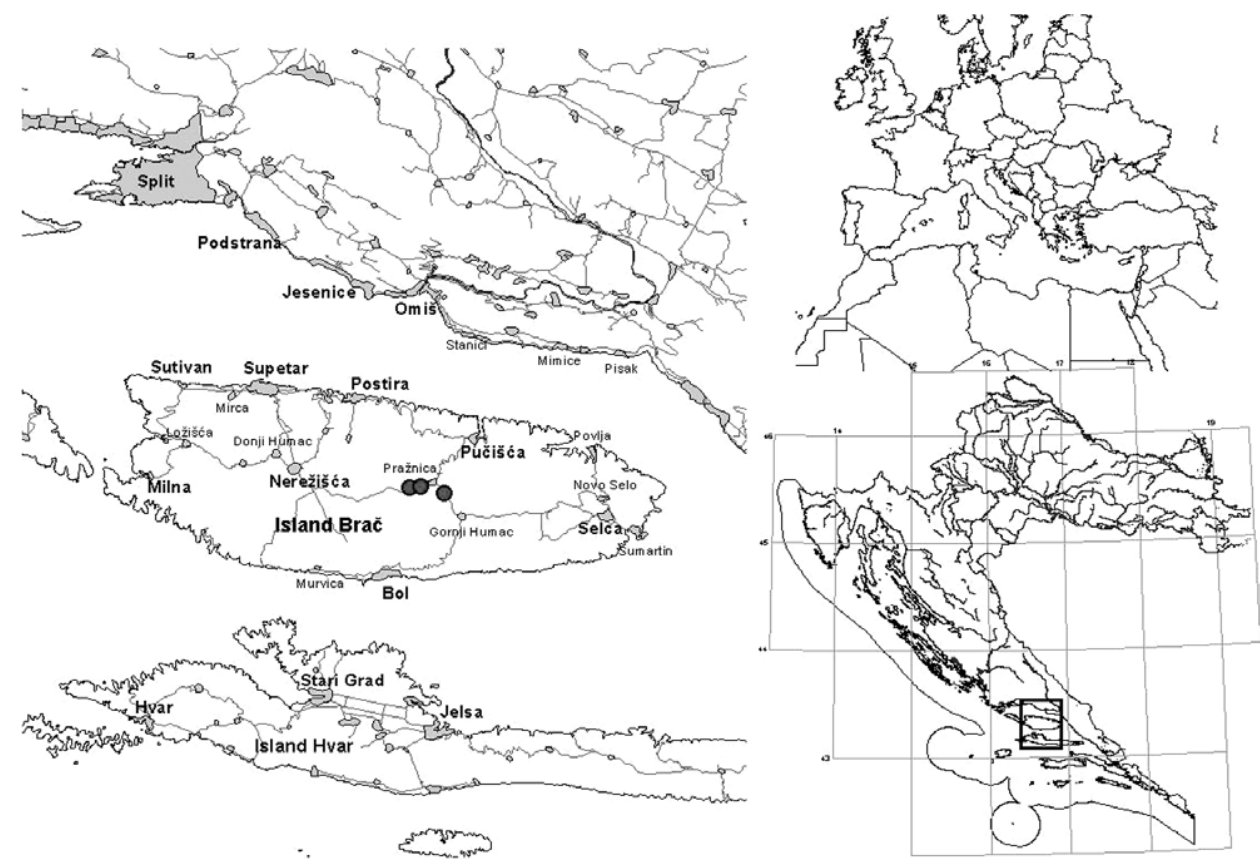

Fig. 2. Distribution map of known localities of Ammi visnaga (L.) Lam. in Croatia 
Tab. 1. New localities of the Ammi visnaga (L.) Lam. on island Brač (Dalmatia, Croatia)

\begin{tabular}{|c|c|c|c|c|c|}
\hline \multirow{2}{*}{ No. } & \multirow{2}{*}{ Locality } & \multirow{2}{*}{$\begin{array}{c}\text { a.s.l. } \\
\text { (m) }\end{array}$} & \multirow{2}{*}{ Habitat } & \multicolumn{2}{|c|}{ Coordinates } \\
\hline & & & & $\mathrm{x}$ & $\mathrm{y}$ \\
\hline 1 & $\begin{array}{l}\text { Island Brač, west from } \\
\text { village Pražnica }\end{array}$ & 457 & $\begin{array}{l}\text { ruderal, pebble embankment } \\
\text { along the road }\end{array}$ & 5636352 & 4798362 \\
\hline 2 & Island Brač, Pražnica & 421 & $\begin{array}{l}\text { ruderal, pebble embankment, } \\
\text { partially stony grassland }\end{array}$ & 5637188 & 4798425 \\
\hline 3 & $\begin{array}{l}\text { Island Brač, east from } \\
\text { village Pražnice toward } \\
\text { village Gornji Humac }\end{array}$ & 388 & $\begin{array}{l}\text { ruderal, along the road on pebble } \\
\text { embankment; part of population } \\
\text { inside vegetation of natural stony } \\
\text { grassland and macchia }\end{array}$ & 5638839 & 4797986 \\
\hline
\end{tabular}

Ecologically, all localities are in the eu-Mediterranean zone of evergreen vegetation of the union Quercion ilicis Br.-B1. (1931) 1936 (HoRvaTIĆ 1963, 1967, 1971) between 380 and $460 \mathrm{~m}$ above sea level. Habitats where species prosper are primarily ruderal. There are pebble embankments alongside the road and semi-natural stony habitats with elements of the vegetation of the association Scolymo-Marrubietum incane Horvatic et Hodak 1956 (TRINAJSTIĆ 2008). In all the more or less separated micro localities, the species is present with the bulk of specimens that successfully develop flowers and fruits. Efficient expansion in natural vegetation is registered as well, mostly in stony grasslands of the association Brachypodio retuso-Trifolietum stellati Horvatic 1958 and macchia of the association Fraxino orno-Quercetum ilicis Horvatić (1956) 1958 (TRINAJSTIĆ 2008). The inclusions in natural compositions are particularly efficient at locality no. 3 (Tab. 1) where Ammi visnaga comes together with taxa characteristic of this kind of habitat, i.e.: Quercus ilex L., Paliurus spina-christi Mill., Phillyrea media L., Fraxinus ornus L., Clematis vitalba L., Juniperus oxycedrus L., Centaurea spinosociliata Seenus ssp. spinosociliata, Brachypodium retusum (Pers.) P. Beauv., Salvia officinalis L., etc.

Ammi visnaga is an indigenous plant of North Africa, West Asia, and a great part of the European Mediterranean (Tutin 1968, Pignatti 1982, BatAnouny et al. 1999, Chevallier 2001, BuENo et al. 2006). As a naturalized species Ammi visnaga appears in North America, Argentina, Chile, Mexico, South-West Asia and some Atlantic islands (KenNER and REQUENA 2001).

The origin of this species in the Croatian flora is not clear. Regarding documented usage of this plant in popular and official medicine (i.e. asthma relief due to its coronary blood vessel dilating effects, a smooth muscle relaxer in the bronchial tissue, vasodilator and helps to relieve spasms, etc.; KenNer and REQuena 2001, CHEVAlLIER 2001), and long tradition of appliances in many parts of the world, we can assume that this species came as a healing plant into the garden flora of the island Brač. It is very difficult to trace when this introduction happened. However, the relatively long presence in culture issuggested by the existence of a Croatian vernacular name - »mrkva divja « (meaning »wild carrot «, because of its high similarity with Daucus species) mentioned by ŠULEK (1879) and used also by ŠUGAR (2008). Consequently, this plant has certainly been cultivated in the coastal area at least longer than 120-150 years.

How long the species has existed as a naturalized plant or when this species secondarily escaped from the garden flora is also not clear. This estimation is particularly difficult, be- 
cause the flora of the island Brač has not been systematically explored for a long time. In any case, based on standardization of the indigenous plants of Croatia (Mitić et al. 2008), for the species A. visnaga we propose the following status: introduced plant (code 2.), noticed outside cultivation (code 2.1.) and locally naturalized (code 2.1.1). Regarding the unquestionably observed trend in successful integration in the natural vegetation, there is no doubt that the appearance of this species outside cultivation is not merely occasional (code 2.1.2). The potential invasive characteristics of the species should be monitored in the coming years.

\section{References}

Batanouny, K. H., Abou Table, E., Shabana, M., Soliman, F., 1999: Wild medicinal plant in Egypt. Palm Press, Cairo.

Bueno, E., Juan, A., Crespo, M. B., 2006: Lactotypification of three endemic taxa of Ammi L. (Apiaceae) from the archipelago of the Azores. Anales de Jardin Botánico de Madrid 63, 31-33.

Chevallier, A., 2001: Encyclopaedia of medicinal plants. Dorling Kindersley, London.

DomAC, R., 1994: Small flora of Croatia (In Croatian). Školska knjiga, Zagreb.

HoRvatić, S., 1963: Phytogeographic placemant and analysis of our seashore in the light of modern phytosociological investigations (In Croatian). Acta Botanica Croatica 22, 27-81.

HoRvatić, S., 1967: Phytogeographic characteristics and analysis of the Yugoslavia (In Croatian). In: Horvatić, S. (ed.), Analytical flora of the Yugoslavia 1. Institut for Botany, University of Zagreb, 23-61.

HoRvatić, S., 1971: Basic vegetation units in the seashore karst and question about additional protection (In Croatian). Proceedings of the Symposium on Nature Protection in Croatian Karst. JAZU, Zagreb, 109-144.

Kenner, D., RequenA, Y., 2001: Botanical medicine, a European professional perspective. Paradigm Publications, Massachusetts.

Mitić, B., Boršić, I., Dujmović, I., Bogdanović, S., Milović, M., Cigić, P., RešEtnik, I., Nikolić, T., 2008: Alien flora of Croatia: proposals for standards in terminology, criteria and related database. Natura Croatica 17, 73-90.

Nikolić, T. (ed.), 2011: Flora Croatica Database (In Croatian). URL: http://hirc.botanic.hr/fcd. Faculty of Science, University of Zagreb.

NikoLić, T., 2006: Flora. Manual for inventory and monitoring (In Croatian). State Institute for Nature Conservation, Zagreb.

Nikolić, T., Bukovec, D., Šopf, J., JelaskA, S. D., 1998: Mapping the flora of Croatia: Possibilities and standards (In Croatian). Natura Croatica 7 (Suppl. 1), 1-62.

Pignatti, S., 1982: Flora d'Italia 2. Edagricole, Bologna.

RuščIć, M., 2010: The flora of the island Brač (In Croatian). PhD Thesis, University of Zagreb.

ŠugAR, I., 2008: Nomenclator Botanicus Croaticus (In Croatian). Matica Hrvatska, Zagreb.

ŠULEK, B., 1879: Yugloslavian vernacular plant names (In Croatian). JAZU, Zagreb. 
RUŠČIĆ M., NiKolić T.

TRINAJSTIĆ, I., 2008: Plant communities of the Republic of Croatia (In Croatian). Academia Scientiarum Forestariarum, Zagreb

Tutin, T. G., 1968: Ammi. In: Tutin, T. G., Heywood, U. H., Burges, N. A., D. M., Valentine, D. H., Walters, S. M., WebB, D. A. (eds.), Flora Europaea 2, 353. Cambridge University Press. 